This PDF is a selection from a published volume from the National Bureau of Economic Research

Volume Title: Innovation Policy and the Economy, Volume 4

Volume Author/Editor: Adam B. Jaffe, Josh Lerner and Scott Stern, editors

Volume Publisher: The MIT Press

Volume ISBN: 0-262-10104-1

Volume URL: http://www.nber.org/books/jaff04-1

Conference Date: April 15, 2003

Publication Date: February 2004

Title: The Gaming of Pharmaceutical Patents

Author: Jeremy Bulow

URL: http://www.nber.org/chapters/c10802 


\title{
The Gaming of Pharmaceutical Patents
}

\author{
Jeremy Bulow, Stanford Business School
}

\section{Executive Summary}

Paragraph IV of the Hatch-Waxman Act provides a mechanism for the litigation of pharmaceutical patent infringement disputes. Many of these cases have been settled with reverse payments by the brand to the generic in return for delayed generic product entry. The Federal Trade Commission (FTC) has contested several of these settlements with good but not complete success. This paper discusses the merits of treating settlements that include side payments or deals that are beneficial to the generic as illegal per se. The paper also describes several additional strategies in addition to side payments, some of which raise serious antitrust problems, that brands have used to keep generics out of the market.

\section{Introduction}

Agreements between brand-name pharmaceutical companies and potential generic entrants that purport to settle patent litigation have been the subject of much antitrust scrutiny over the last several years. These agreements, referred to as Hatch-Waxman agreements, share several features: (1) each occurred in the context of patent litigation between branded and generic pharmaceutical companies that arose under the complex regulatory provisions of the Hatch-Waxman Act; ${ }^{1}$ (2) each involved substantial payments from the brand-name incumbent to the potential generic entrant; and (3) each involved the potential generic entrant agreeing to stay off the market for a defined period of time. The stakes are sometimes quite large; in the biggest settlement, a brand with annual sales of over $\$ 750$ million kept a generic off the market for over six years.

Since March 2000, the Federal Trade Commission (FTC) has announced four prosecutorial actions involving Hatch-Waxman agreements. Three were resolved by consent decrees, ${ }^{2}$ and the fourth was 
litigated administratively and is on appeal to the Federal Trade Commission. ${ }^{3}$ The administrative law judge (ALJ) in this action found that two Hatch-Waxman agreements were legal under a rule of reason analysis.

Private plaintiffs have also challenged Hatch-Waxman agreements. Two federal district courts have invalidated - under a per se theorythree Hatch-Waxman agreements (both cases have been appealed); and at least two other federal district court cases that also involve challenges to Hatch-Waxman agreements are pending. ${ }^{5}$

Taken together, these actions have indicated that Hatch-Waxman agreements involving reverse licensing payments from the brandname company to the generic in return for delayed entry can be problematic under the antitrust laws. Some have argued that these potential problems do not render the Hatch-Waxman agreements per se unlawful because the agreements have two offsetting procompetitive justifications: (1) each claims to settle patent litigation either partially or fully, and (2) with exception of the agreement between Abbott and Geneva, each has allowed for entry by the generic at a date earlier than patent expiration.

Both the FTC and the courts have thus far limited their analysis of any one agreement to the facts pertaining only to that agreement. Thus, a fundamental question remains unanswered: under what circumstances can a Hatch-Waxman agreement be assumed on its face to harm consumer welfare and thus be condemned as per se illegal? ${ }^{6}$

The analysis of this paper implies that:

- Hatch-Waxman agreements in which a brand-name manufacturer pays a potential generic entrant more than nominal consideration in return for staying off the market will harm consumers, and welfare would be increased if such agreements were presumptively unlawful.

- Hatch-Waxman agreements in which a brand-name manufacturer and a potential generic entrant agree on an entry date for the generic product, and at the same time the brand-name manufacturer pays the generic for (seemingly) unrelated rights, will inevitably lead to delayed entry-unless the payment to the generic for the unrelated rights is clearly not more than the generic could have received selling the rights independently. Making such agreements presumptively unlawful would increase welfare.

- Hatch-Waxman agreements in which a brand-name manufacturer and potential generic entrant agree on an entry date for the generic product, but in which no payment is made from the brand-name manu- 
facturer to the generic entrant, may or may not increase consumer welfare, depending on the specific case.

- However, an agreement with no side payments may create an antitrust violation if, because of its interaction with Hatch-Waxman rules on generic exclusivity, it delays entry of other competitors. Even if the agreement involves royalty payments by the generic to the brand and does not deter other entry, an antitrust problem may exist if the generic's marginal per-pill licensing fee exceeds its average per-pill licensing fee. Similarly, pseudo-generic entry as part of a settlement can be problematic if it blocks other entry.

Even beyond the settlement process, the major drug companies have learned to game the system to delay competition, creating a need for a fresh look at the special Hatch-Waxman provisions that govern pharmaceutical patent infringement litigation.

Perhaps no industry, with the possible exception of computers, has contributed more to social welfare over the past fifty years than the pharmaceutical industry. Ironically, for that very reason, vigilant antitrust enforcement in this area is critical. If Coke and Pepsi were allowed to merge, the consequences would be higher prices and lower consumption of soda-arguably a good thing from a welfare standpoint. Artificial price increases for valuable medicines are quite another matter.

Section II provides a brief overview of the key Hatch-Waxman provisions. Section III summarizes the major litigation to date, while Section IV summarizes the results of the 2002 FTC study of HatchWaxman cases. Section V discusses the economics and game theory issues that arise in settlements, ultimately incorporating the key special Hatch-Waxman provisions. Section VI discusses problematic settlements that would be anticompetitive in patent lawsuits more generally, not just under Hatch-Waxman. Section VII concludes with suggestions for reforming the main provisions of the act.

\section{Hatch-Waxman Overview ${ }^{7}$}

Pursuant to the Federal Food, Drug, and Cosmetic Act, a brand-name company seeking to market a new drug product must first obtain Food and Drug Administration (FDA) approval by filing a new drug application (NDA). Included in this filing is information that is expensive and time consuming to create (such as clinical studies) relating to the safety 
and effectiveness of the product. Lourie (1989) found, for sixty-five drugs, that an average of 1.3 years passed between patent grant and the beginning of clinical trials, that clinical trials took an additional 3.8 years, and that FDA review took an additional 2.6 years, leaving a little over nine years left after approval on the old seventeen-year patent system. ${ }^{8}$

The Hatch-Waxman Act increased patent and exclusivity protection for brands while making postpatent entry easier for generics. Manufacturers are allowed to extend one patent for each new chemical entity, with extensions usually on a drug's chemical compound (a product patent) but sometimes on the use of a drug. ${ }^{9}$ Extensions must be applied for within 60 days of FDA approval of the marketing of the drug and may be for up to half the time the drug spent in clinical trials plus all the time it spent in FDA review, subject to a maximum extension of five years and a maximum effective life of fourteen years. The Congressional Budget Office (CBO) estimated that, between 1992 and 1995, of 101 drugs containing new chemical compounds, sixty-seven were eligible for Hatch-Waxman extensions (nineteen having no patent to extend and fifteen having fourteen years of exclusivity already), and of these, sixty-three applied for extensions. On the whole, the average time that a brand has been able to market under patent has increased from about nine to about 11.5 years. ${ }^{10}$

Furthermore, the act provides that the FDA not accept a generic application to produce a new chemical entity for a minimum of five years, benefiting drugs with no or very short patent protection. Since approval of such an application averages over thirty months, effective exclusivity is even longer. Finally, manufacturers can use NDAs or supplemental NDAs to obtain additional years of market exclusivity (as opposed to patent extension) for new dosage forms, for a new use, or for marketing a drug over the counter provided the NDA requires additional clinical testing.

The other side of Hatch-Waxman is its facilitation of generic entry. When an NDA is filed, the brand-name company provides the FDA with information regarding patents covering the product that is the subject of the NDA. ${ }^{11}$ Upon approval of the NDA, the FDA lists the patents in an agency publication commonly known as the Orange Book. ${ }^{12}$ Hatch-Waxman allows a generic firm to file an abbreviated new drug approval (ANDA), which means that it has to show only that its product is bioequivalent to a referenced NDA's brand-name product and also that the generic product has the same active ingredient, dosage form and strength, and proposed labeling as the brand-name prod- 
uct. The act also made clear that generics may use the patent drug to develop their ANDA even before patent expiration. Allowing for ANDA filings has tremendously expanded the availability of generic pharmaceuticals. According to the Congressional Budget Office (1998), the usual period between patent expiration and generic entry has fallen from three to four years to frequently one to three months, the generic share of prescription drug volume rose from 19 percent in 1984 to 47 percent in 1996, and the percentage of top-selling drugs facing generic competition increased from 36 percent in 1983 to nearly 100 percent in 1998.

An ANDA must contain a certification regarding each patent listed in the Orange Book covering a referenced NDA. One of four such certifications are made:

- "Paragraph I Certification" - certifying that patent information has not been filed in connection with an NDA. The FDA may approve immediately an ANDA making this certification.

- "Paragraph II Certification" - certifying that a patent covering an NDA has expired. Again, the FDA may approve immediately an ANDA making this certification.

- "Paragraph III Certification" - certifying that ANDA approval is scught after a listed patent expires. The FDA may approve the ANDA only after such patent expiration.

- "Paragraph IV Certification" - certifying that a listed patent is either invalid or will not be infringed by the generic drug for which the ANDA applicant seeks approval. ${ }^{13}$

Paragraph IV ANDAs implicate two additional provisions of the Hatch-Waxman Act, both of which relate to the FDA's approval of an ANDA. First is the automatic thirty-month stay protection afforded brand-name companies. As part of a Paragraph IV certification, an ANDA filer must provide to the patent holder and NDA filer (which is often, but not always, the same company) a notice of the Paragraph IV certification as well as a detailed statement of the factual and legal bases for the ANDA filer's assertion that a patent is invalid or not infringed on by the ANDA filer's generic product. Once the ANDA filer has provided such notice, a patent holder must file an infringement suit within forty-five days to take advantage of the statutory stay provision. If a suit is not filed within forty-five days, the FDA can approve the ANDA as soon as the regulatory requirements are fulfilled. ${ }^{14}$ Filing 
a patent infringement suit within forty-five days, however, stays FDA approval of the ANDA until the earliest of: (1) the date the patent expires, (2) a court determination of noninfringement or patent invalidity by a court in the patent litigation, ${ }^{15}$ or (3) thirty months after a patent holder was notified of the Paragraph IV certification.

Second is the provision that gives rise to a 180-day exclusivity right. This right is extended to the first company to file a Paragraph IV ANDA. Once such an ANDA filer receives this right, the FDA may not approve any other ANDA for the same drug product until six months after (1) the ANDA filer with the right first markets its product or (2) a court decision declaring the patent at issue invalid or not infringed on, whichever is sooner. ${ }^{16}$ One remarkable consequence of this rule is that if a first filer has not triggered its exclusivity period, say, because it resolved its litigation with the brand-name company by agreeing not to enter the market for several years, the brand-name company could foreclose entry by later filers, even if they clearly did not infringe on its patents, simply by not filing (and losing) an infringement suit. Figure 5.1, taken from the FTC Generic Drug Study, outlines the rules for Paragraph IV certification.

\section{Summary of Enforcement Actions Involving Hatch-Waxman Agreements}

\section{Hoechst-Andrx}

Andrx was the first to file a Paragraph IV ANDA to market a generic version of Hoechst's Cardizem CD and secured the 180-day exclusivity right. Hoechst sued Andrx for patent infringement, triggering a thirtymonth stay of FDA approval of Andrx's product. Hoechst and Andrx entered into an agreement that purported to settle a preliminary injunction in the infringement suit.

The Hoechst-Andrx agreement had four noteworthy provisions. First, Andrx agreed not to market its generic product from July 1998 (when the thirty-month stay expired) until at least January 2000, when Hoechst would allow Andrx to enter the market under a license to its intellectual property. Andrx had the discretion (and was actually paid) to stay off the market longer, until the patent suit was finally resolved. Second, until Andrx marketed its product, Hoechst paid it $\$ 40$ million a year, starting in July 1998. If Andrx won the patent suit, Hoechst would pay it another $\$ 60$ million a year during the time it stayed off 


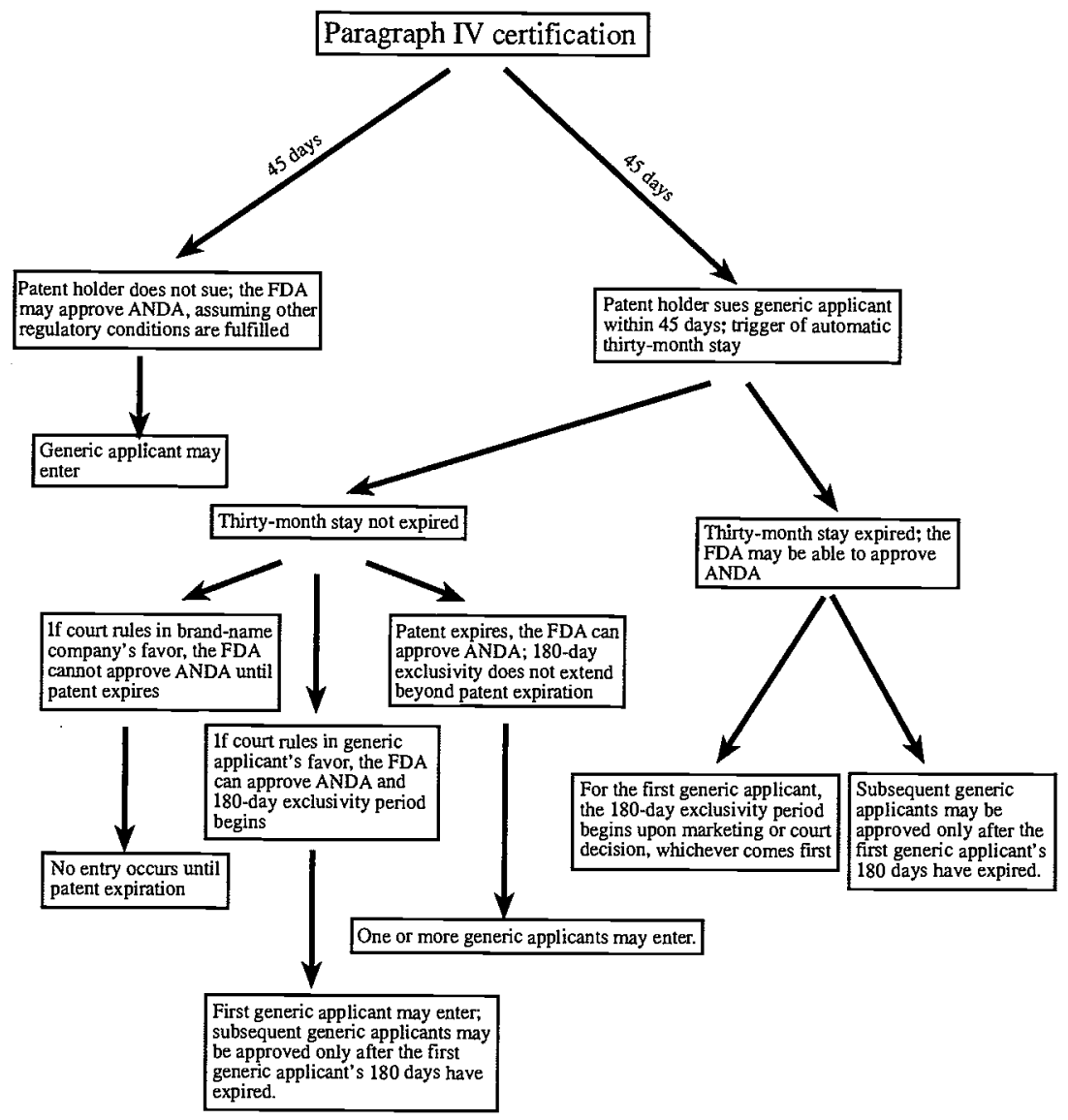

Figure 5.1

Paragraph IV certifications.

Source: Figure 1-2 in Federal Trade Commission (2002).

the market, starting from July 1998. Third, Andrx agreed not to relinquish its 180-day exclusivity right to another ANDA filer, ensuring that this right precluded other potential generic entrants from entering the market. ${ }^{17}$ Fourth, Andrx agreed not to market any generic version of Cardizem CD, even products not at issue in the patent litigation with Hoechst and regardless of whether the products did not infringe Hoechst's patent. $^{18}$

The FTC filed an administrative suit challenging the Hoechst-Andrx agreement, alleging that the agreement as a whole, and in particular the relinquishing and noninfringing restraints, constituted unreasonable 
restraints of trade in violation of Section 5 of the FTC Act. Shortly before trial, Hoechst and Andrx settled with the FTC, individually signing consent orders. These orders preclude both Hoechst and Andrx from entering into (1) an agreement with either a relinquishing restraint or noninfringing restraint and (2) a partial settlement where a generic manufacturer is paid to stay off the market (except if approved by a court and with notice to the FTC).

Private plaintiffs filed suits in federal court, challenging the HoechstAndrx agreement. The cases were consolidated in the United States District Court for the Eastern District of Michigan. The court IIn re Cardizem CD Antitrust Litigation, 105 F. Supp. 2d 682, 699 (E.D. Mich. 2000) (on appeal to the 6th Circuit Court of Appeals)] granted the plaintiffs' motion for partial summary judgment, finding that the agreement constituted a per se illegal market allocation:

On its face, the Agreement: (1) restrained Andrx from marketing its generic version of Cardizem CD in July 1998 when FDA approval was expected and obtained; (2) restrained Andrx from marketing other bioequivalent or generic versions of Cardizem $C D$ which were not at issue in the pending HMRI/Andrx patent case, ... and thus restrained Andrx from marketing non-infringing or potentially non-infringing versions of Cardizem CD; and (3) restrained Andrx from relinquishing or otherwise compromising its right to the 180-day period of exclusivity it obtained under the Hatch-Waxman Amendments. The HMRI/ Andrx Agreement thus inhibited rather than enhanced generic competition for Cardizem CD and allocated the entire United States market for Cardizem CD and its bioequivalents to HMRI during the life of the Agreement.

\section{Abbott Geneva}

Geneva was the first to file a Paragraph IV ANDA to market a generic version of Abbott's Hytrin and was awarded the 180-day exclusivity right. Abbott sued Geneva for patent infringement, triggering a thirtymonth stay of FDA approval of Geneva's product. The parties entered into an agreement that purported to settle a preliminary injunction in the patent litigation. Under the agreement, Geneva was precluded from marketing its generic version of Hytrin until final resolution of the patent litigation and, in return, was paid $\$ 54$ million a year (for the time it stayed off the market). Like the Hoechst-Andrx agreement, this agreement also included a relinquishing restraint and a noninfringing restraint.

Zenith also filed a Paragraph IV ANDA to market a generic version of Hytrin. Zenith sued Abbott for wrongful patent listing in the FDA's 
Orange Book, and Abbott counterclaimed, alleging patent infringement. The two parties fully settled their litigation. Under their settlement, Abbott agreed to pay Zenith $\$ 6$ million a quarter in return for Zenith's agreeing not to market a generic version of Hytrin until the expiration of Abbott's patents or until another generic version of $\mathrm{Hy}$ trin entered the market.

The FTC issued a complaint alleging that the Abbott-Geneva agreement constituted an unreasonable restraint of trade in violation of Section 5 of the FTC Act. (The FTC did not challenge the Zenith agreement.) Abbott and Geneva signed a consent order with the FTC pursuant to which neither firm can enter into (1) an agreement with a relinquishing restraint or a noninfringing restraint and (2) a partial settlement in which a generic manufacturer is paid to stay off the market (except if approved by a court and with notice to the FTC).

Private plaintiffs filed suits in federal court, challenging Abbott's agreements with both Geneva and Zenith. As in Hoechst-Andrx, the court granted the plaintiffs' motion for partial summary judgment, finding that both agreements constituted per se illegal market allocations. [See In re Terazosin Hydrochloride Antitrust Litigation, $164 \mathrm{~F}$. Supp. 2d 1340 (S.D. Fla. 2000) (on appeal to the 11th Circuit Court of Appeals).]

\section{Schering-Upsher-Smith}

Upsher-Smith was the first to file a Paragraph IV ANDA to market a generic version of Schering's K-Dur 20 and was awarded the 180-day exclusivity right. Schering sued Upsher-Smith for patent infringement, alleging that Upsher-Smith's generic product infringed on a patent that expired in 2006. On the eve of trial, in June 1997, Schering and UpsherSmith entered into an agreement that fully settled the parties' patent litigation. Under the agreement, Upsher-Smith was precluded from marketing any generic version of Schering's K-Dur 20 until September 2001. Also under the agreement, (1) Upsher-Smith was paid $\$ 60$ million and (2) they extended to Schering several licenses to products unrelated to K-Dur 20.

ESI Lederle also filed a Paragraph IV ANDA to market a generic version of Schering's K-Dur 20 and was sued by Schering for patent infringement. In January 1998, Schering and ESI settled their suit under the following terms: ESI would not market its generic version of K-Dur 20 until January 2004 and would receive up to $\$ 15$ million for staying 
out of the market (and another \$15 million in return for extending to Schering several licenses unrelated to K-Dur 20). The FTC challenged Schering's agreements with Upsher-Smith and ESI Lederle. ESI settled with the commission. Under the terms of this settlement, ESI cannot enter into an agreement with a noninfringing restraint, nor can it enter a full settlement in which a generic manufacturer is paid to stay out of the market (except if approved by a court and with notice to the FTC).

The FTC filed an administrative complaint against Schering and Upsher-Smith, challenging both of Schering's agreements under Section 5 of the FTC Act. An administrative law judge found both of Schering's agreements lawful under the rule of reason. [See In the Matter of Schering Plough Corp. et al, No. 9297, 2002 WL 1488085 (F.T.C. June 27, 2002) (on appeal to the Federal Trade Commission).] The ALJ reasoned that the agreements should be analyzed under the rule of reason because both agreements had procompetitive aspects: (1) they provided for generic market entry prior to the patent expiration date and (2) they fully resolved patent litigation (Schering, pp. 97, 99-100). In addition, the ALJ reasoned that the agreements were lawful under the rule of reason because Schering's patent was presumed both valid and infringed on and anticompetitive effects could not therefore be presumed (Schering, pp. 100-101). The ALJ also found that Schering's \$60 million payments to Upsher-Smith were in consideration for licenses unrelated to K-Dur 20 and not in return for Upsher-Smith's agreeing to stay off the market.

\section{Bristol-Schein}

In August 1992, Schein filed a Paragraph IV ANDA with the FDA to market a generic version of Bristol's BuSpar and was sued by Bristol for patent infringement. In December 1994, Bristol and Schein fully settled their litigation, under which Bristol paid Schein $\$ 72.5$ million to abandon its challenge to Bristol's patent (which required that Schein stay out of the market until patent expiration). Bristol signed a consent decree with the FTC, precluding it from entering into a patent settlement in which an ANDA filer is paid and agrees not to market a generic product.

\section{Results of the FTC Generic Drug Study}

In its 2002 Generic Drug Study, the FTC provided details on the history of Hatch-Waxman litigation and settlements. From 1984 through 
December 31, 2001, 483 ANDA filings involved 130 unique brand-name drug products. The FTC study included ANDA filings made after January 1,1992 , which involved 104 products.

In twenty-nine cases (out of 104), the brand-name company (brand) did not sue the first generic applicant. ${ }^{19}$ Of the remaining seventy-five cases, twenty-two are still pending, with fifty-three resolved either through litigation or settlement. Of the fifty-three, the brands won in court eight times, with one case on appeal, and the generic companies (generics) won twenty-two times, with four still on appeal. In two cases, the patent expired before litigation was resolved, and in one case, the NDA was withdrawn. In twenty cases, a settlement was reached.

The FTC study included twenty final and four interim settlements. In nine of the final settlements, the brand-name company agreed to pay the generic. In seven of the twenty, the brand granted a license to the generic. In two settlements, the generic was allowed to market the brand's product as a generic product under the brand's NDA rather than under the entrant's ANDA. A brief summary of sixteen of the settlements is provided in tables in the FTC Generic Drug Study, and they are reproduced here as tables 5.1 and 5.2. More details on some of the cases are provided in the FTC study.

Of the settlements listed in table 5.1, the entry labeled $\mathrm{E}$ involved marginal royalty rates above average rates and could be interpreted as the equivalent of a deal that included a $\$ 9$ million cash payment to the generic. The other settlements were all structured as conventional licensing agreements, with the generics paying an average licensing fee that was at least as high as the marginal fee. As I will discuss below, it is also conceivable that some of these other settlements may have created competition problems because of their interaction with the 180day exclusivity law.

The settlements listed in table 5.2 are another matter entirely. In six of the cases, it appears that the generic received cash and agreed to stay out of the market until patent expiration, though in one case the remaining time was only four months. In the two other cases, generic entry was substantially delayed, though it was to occur prior to patent expiration. These eight agreements included additional conditions, for example, restricting the generic from aiding any other generic applicant. FTC employees regard such settlements as blatantly anticompetitive.

Brands also filed suits against forty-three second filers and reached settlements in seven of these cases. Only one case involved a brand 


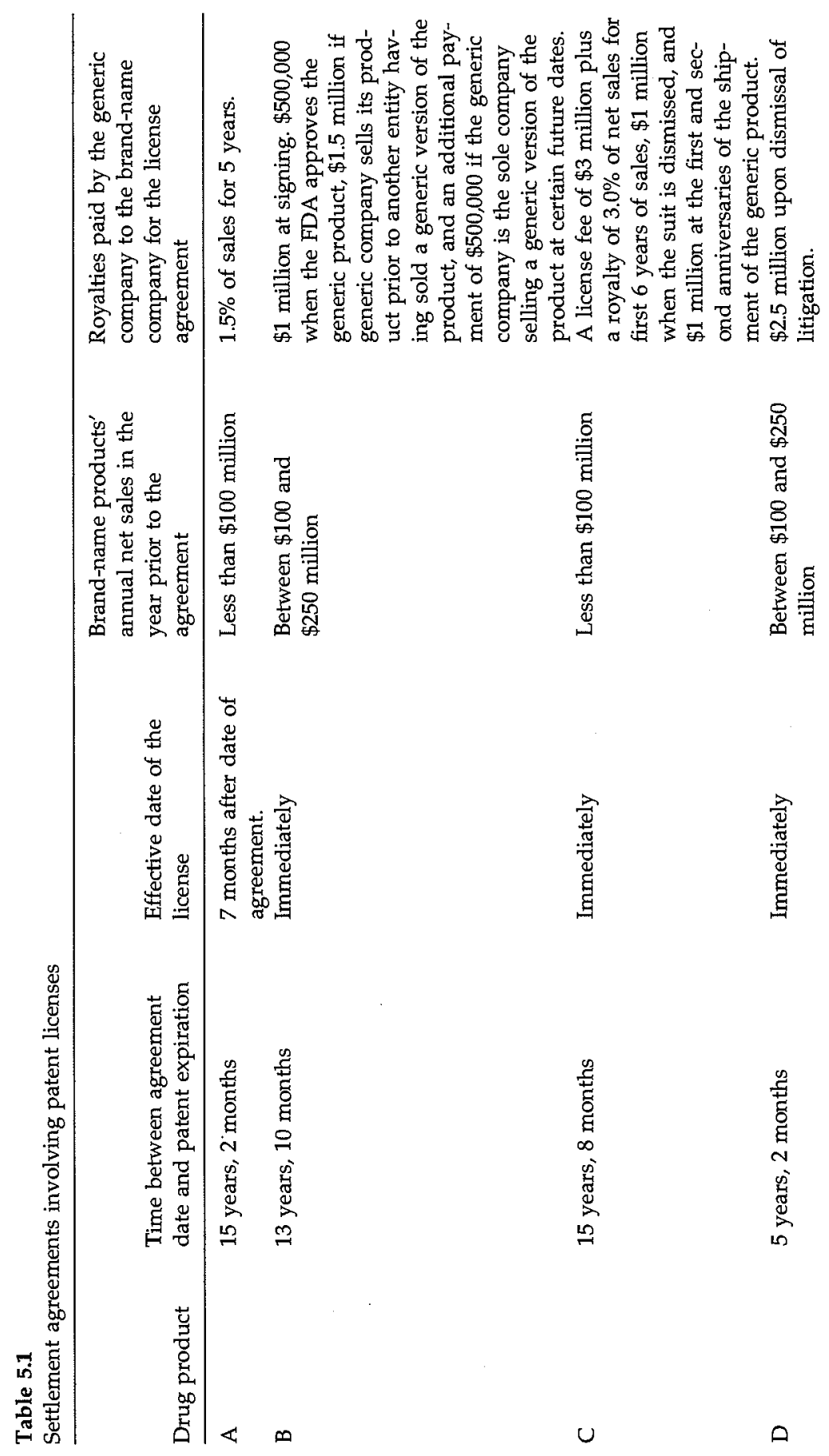




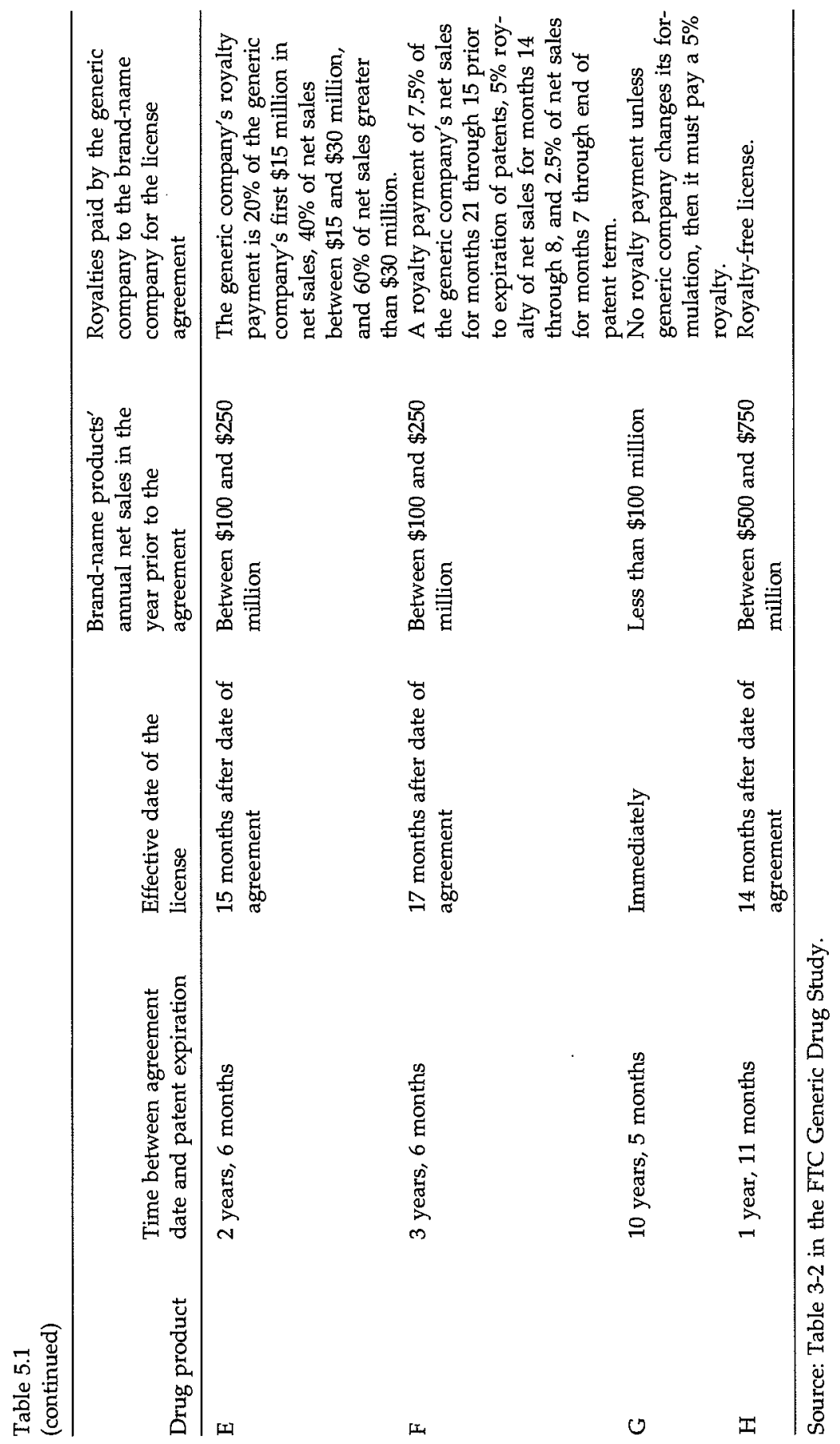




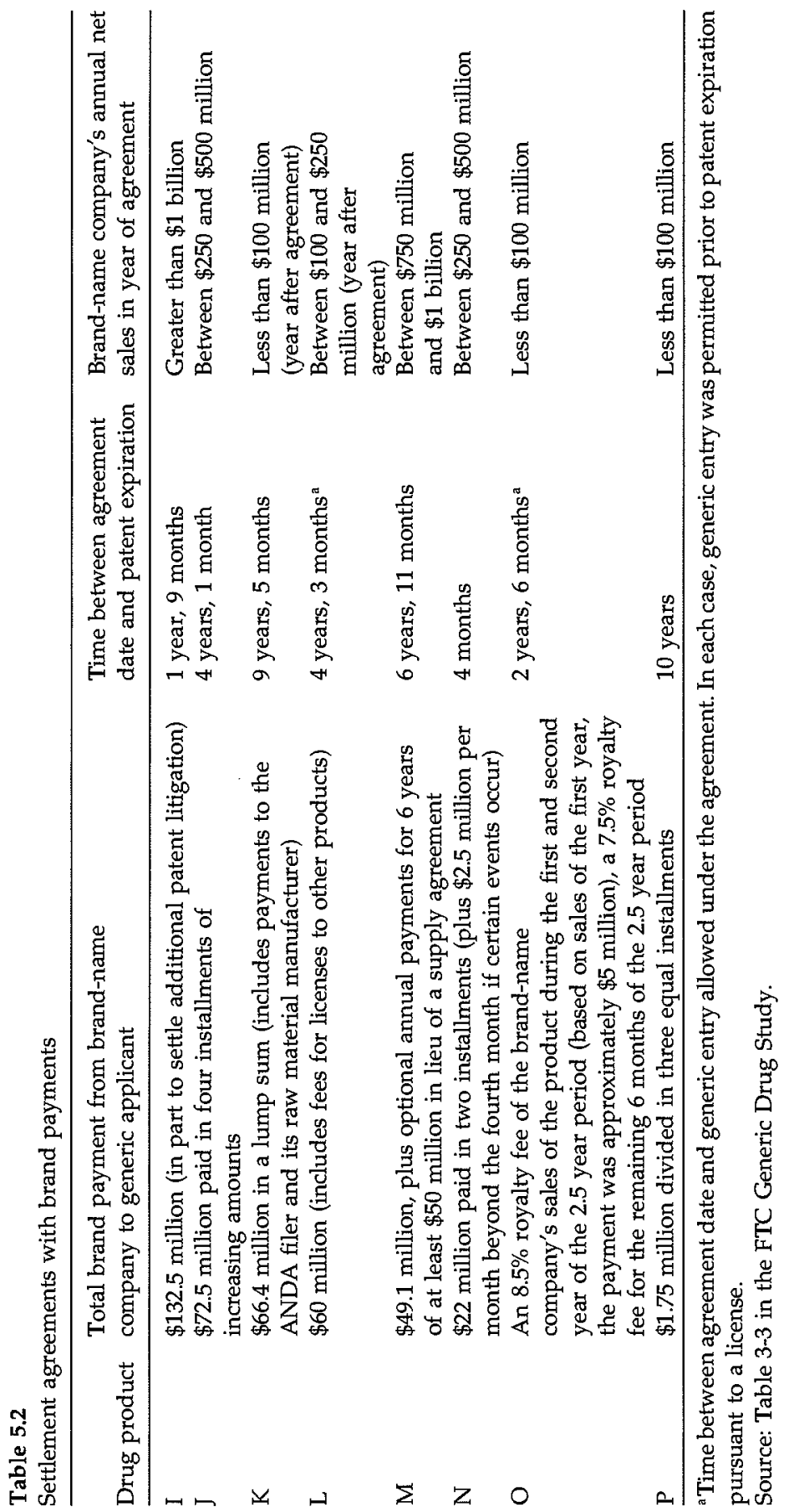


payment. Finally, there were six agreements with generic entrants, four of which focused on the 180-day exclusivity provision. In one case, the second generic paid the first to waive exclusivity; in another, the first relinquished its rights so that the second ANDA could be approved and the first generic marketed the second generic's product. (The first generic's product was not ready for approval.) The FTC regarded all but one of the agreements as procompetitive. It charged that the last agreement unreasonably restrained competition between the entrants. ${ }^{20} \mathrm{I}$ will constrain the analysis to cases where there are no more than two potential entrants and not consider agreements between the two.

\section{Economics and Game Theory Issues}

In this section, I begin with a simple model of Paragraph IV settlements, which we then use to illustrate the key economic and game theory issues.

\section{A Simple Model of Settlements Without the Thirty-Month and 180-Day Rules}

We assume that there are two potential entrants into a contested patent market. In the absence of any settlements, the first filer's case will be resolved at time 0 and the patent will expire at time 1 . A second filer's case would be resolved at time $R, 0<R<1$.

All firms are risk-neutral and litigation costs are vanishingly small. ${ }^{21}$ For simplicity, I assume that the second filer will litigate its case. There are four litigation possibilities involving whether the first or second filer wins or loses its case. I define $P_{W W}$ as the probability that both the first and second filers will win their cases, $P_{W L}$ as the probability that the first firm wins and the second firm loses, and so on. I assume that the outcomes of the cases are at least weakly positively correlated, so that $P_{W W} \cdot P_{L L} \geq P_{W L} \cdot P_{L W}$.

There will be two key variables in our analysis. The first is whether the ratio of the benefit to a brand of excluding a sole generic entrant to the cost of having a second entrant (which will be labeled $B_{1} / B_{2}$ ) is greater than or less than the ratio of the value to an entrant of being the sole generic compared to the value of being one of two entrants (which will be labeled $G_{1} / G_{2}$ ). The second will be whether the actuarially fair settlement date at a zero royalty with the first generic, $S=P_{L W}$ $+P_{L L}$ is greater than or less than $R$. 
I assume that $B_{1} / B_{2} ; G_{1} / G_{2}$; and the ratio of consumer benefit derived from the first and second entrants, $C S_{1} / C S_{2}$, are all greater than 1. Furthermore, it seems reasonable to assume that $B_{1} / B_{2}>C S_{1} / C S_{2}{ }^{22}$ I assume that the parties will reach a Nash bargaining solution, negotiating only over a date for royalty-free entry.

In analyzing a settlement, it is useful to think that there are four different possible types of days: monopoly days, triopoly days, and duopoly days with either the first or second filer as the unique generic. Because the second filer's entry is independent of any settlement with the first filer, a settlement essentially involves either creating more triopoly days, by the brand allowing the entrant to be in the market on days when otherwise only the second generic would be selling, in return for the generic agreeing to stay out of the market on days when it would have been the only generic, or vice versa. If $B_{1} / B_{2}>G_{1} / G_{2}$, then the parties will want to design settlements that include more monopoly and triopoly days; if it does not, they will prefer a settlement with fewer monopoly/triopoly and more duopoly days.

There are four relevant cases:

1. $S<R$ and the ratio assumption $B_{1} / B_{2}>G_{1} / G_{2}$ holds. In this case, an actuarially fair settlement will automatically increase the expected number of monopoly days to $S$, from $S-(1-R) P_{L W}$. Because the second filer's entry is unaffected, the actuarially fair settlement must create the same number of monopoly days (benefiting the brand) as triopoly days (benefiting the generic). This would be a very profitable deal for the brand but unprofitable for the generic, so an actual settlement would have to be restructured to make the generic better off. This would be done through a settlement date that would be earlier than the actuarially fair date, thereby reducing the number of expected days acting as the exclusive entrant that the generic would be sacrificing to become at least a triopolist after the second filer's litigation is resolved. In the end, the settlement would be an agreement to trade off the creation of monopoly and triopoly days at a rate somewhere between $B_{1} / B_{2}$ and $G_{1} / G_{2}$.

Whether consumers gain from the settlement depends on whether the ratio of additional created triopoly days to new created monopoly days exceeds $C S_{1} / C S_{2}$. If $G_{1} / G_{2}>C S_{1} / C S_{2}$, then consumers will surely gain; if not, consumers may or may not come out ahead. ${ }^{23}$

2. $S>R$ and the ratio assumption holds. If there is a low correlation between the brand and the entrant winning their cases, then the same 
results as case 1 apply: mutually profitable settlements would be actuarially early and likely benefit consumers. But if there is a high or perfect correlation in the outcomes of the cases, then a delayed entry settlement would not be feasible. The problem, illustrated neatly by a perfect correlation in litigation outcomes, is that without settlement there will never be a day in which the second filer would be the only entrant, but with a settlement, there would be $S-R$ days after the second filer's case was resolved but before the first filer's settlement came into effect, and the second filer might be the only generic. As discussed in case 1, the focus of a settlement would be to eliminate such days, so settlements would provide losses rather than gains. ${ }^{24}$

3. $S<R$ and the ratio assumption is reversed. In this case, the objective of any settlement would be to make a trade that turned monopoly and triopoly days into duopoly days. But as shown in case 1 , a settlement will increase the number of monopoly days. So a settlement would not be mutually profitable for the parties.

4. $S>R$ and the ratio assumption is reversed. Now the viability of a settlement depends on the correlation of litigation outcomes. With no correlation, a settlement for a date of certain entry would necessarily increase the number of monopoly days and not be viable. If the outcomes were highly positively correlated, however, the noncontingent entry of the first filer on a date after $R^{25}$ would create some potential duopoly days and therefore be profitable for the firms. Since consumers always have a relatively high value for the second entrant relative to the brand, however, settlements of this sort, which would lead to entry after the actuarially fair date, would reduce consumer surplus.

Which case is most likely? Empiricists have often modeled generic competition as similar to Cournot competition with linear demand, with overall market size independent of generic entry. ${ }^{26}$ In this case, the ratio assumption is likely to hold, settlements are viable without any subsidies, and consumers will benefit from a settlement, provided that the settlement does not affect the timing of subsequent entry (cases 1 and 2). In other cases, however, settlements with noncontingent entry dates will not be viable without a subsidy (case 3), or settlements may even reduce welfare (case 4 ).

Whether risk aversion would act in favor of earlier or later entry would depend on both the risk preferences of the parties and the relative amount of money they have at stake. If the generic is owned by a large company, it might be roughly as risk-averse as the brand. Be- 
cause the brand has much more money at stake, it would be relatively more eager for a settlement if the two parties are risk-averse, and this situation would help both the generic and consumers. ${ }^{27}$ Of course, basic capital market theory would say that if the litigation risk is nonsystematic and the firms' managers act as fiduciaries for well-diversified stockholders, then the firms should be risk-neutral regarding the litigation.

As an empirical matter, risk aversion should not be terribly relevant in most cases. The market values of the large pharmaceutical companies (pharmas) are enormous relative to the amount at stake in most of these cases, even if the absolute dollars may be in the hundreds of millions. The point is illustrated in the next section in a discussion of the Schering-Upshur settlement.

Similarly, one might consider a settlement that gives the entrant an immediate license at a constant marginal royalty rate. In this way, the consumer pays more than if the license is royalty-free but gets the benefits of a generic for a longer period of time. In most models of competition between undifferentiated products and firms with equal marginal costs, this kind of settlement would seem to be better for consumers. Small reductions in price from the monopoly level, as created by entry with high royalty costs, cause small drops in profits but first-order gains in consumer savings. Since the entrant's gain is likely to be roughly proportional to the incumbent's loss, ${ }^{28}$ it follows that settlements that allow entry sooner, albeit at somewhat higher prices, would be better for consumers. On the other hand, economies of scale might make delayed entry with a royalty-free license both more efficient and better for consumers. ${ }^{29}$

Introducing litigation costs into the analysis should make settlements less favorable to consumers. Because the pharmas have so much more money at stake than the generics, the relative cost of litigation to the cost of settlement is lower for them, so standard models would predict that they would be less willing to achieve a settlement. For example, a Nash bargaining solution would imply that if the brand has three times as much money at stake as the generic, then litigation costs would benefit the brand in settlement negotiations as long as the cost of presenting its case is not more than three times as high as the generic's cost. One usually does not think of the high cost of litigation as a strategic benefit for small companies in battles with big ones.

The conclusion is that the results in the basic case with risk-neutral bidders and no litigation costs stand up well: while settlements without 
side payments might not always be feasible when I abstract from the special Hatch-Waxman rules, when they are, it is reasonably likely though not certain that they will be pro-competitive. However, in the cases where a subsidy is required to make a settlement feasible, as when the ratio assumption is reversed, the settlement that results would likely harm consumers.

\section{The 180-Day Rule}

The existence of the 180-day rule obviously acts to the detriment of second entrants, even more so if there are settlements with the first filer, and especially if there is likely to be a correlation in the litigation results. First, consider the case where litigation is uncorrelated, but a second entrant cannot enter the market until some time (e.g., 180 days) after the first entrant. If the first entrant loses its case, however, then the second entrant can enter immediately on winning. Now the private, as opposed to the social, incentives for settlement are much more compelling. The extreme gaming situation occurs when the second entrant's case is relatively strong and the first entrant's case is relatively weak. Then the optimal solution for the brand-name company and the entrant might be to negotiate a settlement allowing the entrant to come in 180 days or even less before the patent expires. The brand-name company could then avoid suing the second entrant, which would then not be allowed to enter until the end of the patent's life. It would make sense to sue the second entrant only if it had a weak enough case that the expected benefits from defeating it in court, and thereby eliminating it as a second entrant, were great enough to compensate for possibly losing the case and causing the 180-day clock to start at $R$, rather than at the entry time negotiated with the first entrant.

The 180-day rule was put in place as an incentive for generics to become first filers, at a time when few patents were challenged. ${ }^{30}$ Putting aside for the moment the merits of the rule as originally intended, the rule as currently interpreted creates significant gaming opportunities. As I will discuss in Section VII, one possible modification would be to require any settlement to include a forfeiture of the exclusivity period. This requirement would eliminate the ability to lock out second entrants without a lawsuit and take away the incentive to settle a risky litigation for a delayed entry date because doing so would guarantee the 180 days. 


\section{The Thirty-Month Rule}

The most obvious problem with the thirty-month rule is that, because the FDA does not monitor Orange Book listings, a generic cannot enter a market earlier even if the brand's patent claim were not strong enough to persuade a judge to grant a stay against the generic's entry. If the patents in question concerned the brand's new chemical entity, this would be less of an issue: litigation would typically take about thirty months anyway, and even without litigation it would take a couple of years on average for an ANDA to be approved. Finally, the rule could be interpreted as being a roundabout way of granting a new chemical entity seven and a half years of exclusivity rather than five.

But many of the challenged patents do not concern the new chemical entity, and recently, as brands have filed more and more patents, litigation has often extended well beyond thirty months. Firms are allowed to add additional patents to the Orange Book at any time, and one way that brands have gamed the system is to list additional patents when the generic's initial litigation is well advanced. Brands have filed metabolic patents, ${ }^{31}$ polymorph patents, ${ }^{32}$ and process patents ${ }^{33}$ in the Orange Book. Because the FDA does not monitor Orange Book listings, these patents can be listed even if there is little chance that it is relevant to the patent litigation. ${ }^{34}$ Indeed, some brands have engaged in "double patenting": listing two essentially identical patents that expire on the same day at two different times, ${ }^{35}$ with the only net effect being to force a restart of the thirty-month clock.

This ability to extend litigation, even when the later filed patent is of questionable value, obviously postpones legitimate entry. For example, the first ANDA for Paxil was filed in March 1998, and GlaxoSmithKline's fifth thirty-month stay is scheduled to expire in September 2003. Furthermore, the threat of such filings will harm the ability of a generic to obtain a fair settlement of its claims.

One additional factor is likely to make settlements a bit worse for both second entrants and consumers. That is, a Paragraph IV filing can be made based on patent noninfringement, invalidity, or both. If the first filer wins its litigation based on invalidity, a second entrant will automatically be able to enter the market after 180 days and will no longer have to litigate. In a settlement, it will be in the interest of both the first entrant and the brand to maintain that the patent is valid, requiring the second entrant to litigate and face the thirty-month stay. 


\section{Shared Exclusivity}

One of the technical problems that the Food and Drug Administration has had to deal with in a world with multiple Orange Book listings made over time on the same medicine is what to do when different generics are the first to file on different patents. For example, Andrx and Genpharm were the first to file on different patents regarding Prilosec (omeprazole). ${ }^{36}$ By October 2001, there were no thirty-month stays barring entry, and AstraZeneca had acknowledged that the Andrx and Genpharm products did not infringe on the remaining unexpired patents. The dilemma for the FDA was that the law could be read as saying that Andrx could not enter and begin its exclusivity until after Genpharm's exclusivity had expired, and vice versa. So having the two generics meant that perhaps neither could enter.

The FDA debated between a one-first-applicant rule, which would give exclusivity to the first filer against any patent, or a shared-exclusivity rule, which would allow all the first filers in at the same time, to the exclusion of other generic firms. The decision was to go with the sharedexclusivity approach as being more consistent with the statutory language. While this decision meant that no generic would really have full exclusivity in these situations, it was felt that the 180-day rule did not guarantee a period of exclusivity for two other significant reasons as well. A district court decision could trigger the start of the exclusivity period before the ANDA was approved, and if the generic could not be sufficiently confident of winning the appeals case, it might prudently not enter, even though its exclusivity period would be running.

\section{Problematic Settlements}

While the 180-day and thirty-month rules create numerous problems for competition, there have been several settlements where the brand and first filing entrant have agreed to settle their disputes in ways that would raise flags, even in the absence of these rules, because of the way brands have used the system. The key types of settlements are discussed below.

\section{Cash Side Deals}

Settlements where the brand-name company pays the entrant cash as part of a deal that leads to delayed entry into the market raise immediate 
flags. While arm's length deals with no cash changing hands can be procompetitive (though they are less likely to be so because of the 180day rule), adding cash to the deal cannot be. Simply compare the settlement that would be made in the absence of a $\$ 50$ million transfer from the brand to the generic, with the settlement made with the cash payment. It is clear that in return for the cash, the entrant will agree to come to market later. The consumer clearly loses from this part of the deal.

As a numerical example, consider a case with one potential entrant. The entrant has a 50-50 chance of winning its case. If it enters, it will earn $\$ 100$ million, while the brand's profits will be reduced by $\$ 300$ million. Both sides are risk-neutral, litigation costs are negligible, and the parties negotiate a Nash bargaining solution. Without a cash side payment, the entrant would be allowed to come in halfway through the remaining patent life. The brand would lose $\$ 150$ million, the entrant would gain $\$ 50$ million, and consumers would pay about $\$ 100$ million less for their medicines. But if cash payments are allowed, then the solution is for the brand to pay the entrant $\$ 75$ million to stay out of the market until the patent expiration. That would give both the brand and the generic three-fourths of their expected profit from winning the litigation. The problem is that this comes at the expense of consumers losing their expected savings.

One response from parties has been that a deal was simply not feasible without a cash payment (say, in our earlier example, that the ratio assumption did not hold). The argument has to be that no efficient settlement would benefit both parties because consumers would get more than 100 percent of the benefits. But stating that any possible deal would be unprofitable to either one or both parties, but for allowing the brand to purchase some extra monopoly time, puts a limit on how efficient the deal must have been without the cash. Perhaps one can argue that sometimes marginally efficient deals don't get done because of bargaining breakdowns, but if the deal was only marginally efficient, then there is the issue of whether such deals are worth subsidizing at the cost of departing from one of the most basic antitrust principles: you don't get to pay your competitor to stay out of your market. Certainly the authorities would never permit a merger that would not get done but for an explicitly anticompetitive element. Furthermore, allowing the subsidization of these deals through the purchase of additional monopoly time would mean that some deals that were inefficient would now get done. 
A second argument is that allowing brands to buy settlements is a way of expanding the patent life on drugs. In equilibrium, allowing this behavior will lead to more intense competition in the development of new pharmaceuticals. It is entirely possible that increasing the exclusivity rights and patent lengths of pioneer pharmaceutical manufacturers would be good social policy, but the point here is that, regardless of whether that is true, it is efficient policy to differentiate between patents that are valid and those that are not. If we allow buyoffs, we are effectively permitting the drug companies to convert all patent claims, valid or not, into extended monopolies. Welfare is increased if we allow those with legitimate patents to have longer monopolies than those without, thereby enabling longer exclusivity for legitimate patents at any given total cost.

Third, risk aversion and litigation costs might make settlements efficient, and public policy is to encourage settlement of legal disputes. This is true, but the risk-aversion argument applies to the settlement that would occur without the incremental payment for extra monopoly time. The brand's risk of generic entry, and the generic's similar risk, is resolved by a deal without cash payments. The postponement of the entry time due to a cash payment does not eliminate risk, again unless the deal were so marginal that it would not have been done otherwise.

Furthermore, any serious analysis of the risk-aversion issue would imply that it should have little empirical bearing on all but the very largest settlements. Consider Schering-Upshur-Smith. Schering paid $\$ 60$ million before taxes. Assuming a 3-to-1 ratio in Schering's margins to Upshur-Smith's and ignoring any anticompetitive side effects on the deal regarding other potential entrants, the side payments purchased something between $\$ 60$ and $\$ 180$ million of pretax monopoly profits, significantly less after taxes. Schering's market value is about $\$ 25$ billion. Even if the company's management were risk-averse with regard to the settlement, the discount for risk aversion for a bet representing less than $1 / 2$ percent of the company's value should have been exceptionally small. ${ }^{37}$ Also, if Schering were risk-averse, it could have reduced risk at no sacrifice in fair market value by, say, hedging out pension liabilities with bonds rather than ploughing pension assets into stocks-so why settle a case at less than fair market value ${ }^{38}$

Finally, companies have argued to the FTC that the informational asymmetries between the brands and generics make it more difficult to work out an efficient deal, and therefore it might be appropriate to 
allow some subsidy through the purchase of additional monopoly time to "grease" the deal. ${ }^{39}$ Two kinds of asymmetries that cover the basic cases are (1) the entrant has better information than the brand-name company about whether it has a viable product to sell, and (2) the brand-name company has better information than the entrant about whether it has a substitute product in the pipeline that will reduce the value of deferred entry.

But this justification for the deals would imply endorsing major departures from standard antitrust policy to facilitate some marginally efficient (as well as some marginally inefficient) deals. Beyond that, it is not clear why the appropriate way to resolve these uncertainties is by cash payments from the brand to the generic for extra monopoly time. For example, if the entrant is better informed about the time that its product will be ready, it could signal this by offering to pay the brand a license fee for earlier entry. There are no competitive problems with cash transfers that go the "right way." Another acceptable solution would be for the generic to offer to buy a license with a high royalty rate for the last years and a low rate for the first years. This offer would signal that it does have a viable product that will be ready sooner rather than later. In the case where the brand has better information about when a substitute product is likely to diminish the market for the current medicine, it can similarly negotiate a settlement that allows for earlier entry in return for high royalty payments on all sales made after a certain date. This solution would effectively signal to the generic that the brand did not expect a substitute to take over the market any time soon.

A final argument that was made to the FTC was that, in some cases, the generic claimed it did not in fact have a legitimate product ready to sell, so any cash it could receive from the brand for delayed entry would not have any adverse effect on the consumer. Put aside the difficulty, on the FTC's part, of evaluating the remarks of a party that claims to have misrepresented itself in the settlement negotiations. Consider the consequence of having a rule saying that cash settlements were to be allowed only in cases where the entrant in fact had no ability to enter. Why would a brand make a cash payment under such a rule? Therefore, such a rule would appear to be the equivalent of a rule that simply prohibited all cash payments. In a civil litigation, where damages to consumers from a settlement are at issue, the fact that the generic did not have a product to sell would be relevant. 


\section{Cash Payments Until the Resolution of Litigation}

In the Hoechst-Andrx case, Hoechst agreed to make quarterly payments to Andrx in return for Andrx staying out of the market after the automatic thirty-month stay expired and until its litigation was resolved. ${ }^{40}$ There are good reasons why a generic might choose to stay out of a market until litigation is resolved. If it enters, it will be liable for damages equal to the lost profits of the brand. ${ }^{41}$ But that stipulation does not require allowing for payments to the generic. There are also good reasons why a brand might request a stay against a generic's entry, especially if it feels that it has a good case and the generic is unlikely to have the money to pay a damage claim. But the thirtymonth rule does not preclude the brand from going to court to extend the stay. The only reason to purchase a stay is to guard against the possibility that a court would refuse to grant one and the generic would come to market, and in that circumstance we would not allow a payment.

Finally, payments as structured by Hoechst-Andrx, in which the amount paid to the generic is increasing the length of the litigation rather than a lump sum, give generics an additional incentive to delay entry. The reason is that the payment structure can create an incentive for the generic to drag out the litigation, particularly if either (1) it is likely that it will lose, or (2) there is a second generic who will likely be able to enter after 180 days, regardless of when the litigation is resolved.

\section{Complex Side Deals}

Understanding that pure cash payments would present an antitrust problem, some firms have attempted the following structure. The generic agrees to delayed entry, the brand-name company provides the entrant with cash, and the entrant provides the brand with some other consideration, such as licenses to patents that the generics hold. This was the basic structure of the Schering-Upshur-Smith deal that the FTC challenged.

Part and parcel of the argument here must be that additional issues will make the larger settlement possible. For example, assume that $A$ and $B$ each own an asset. $A$ is known to have a value of between 50 and 100 for asset 1 , which it owns, and a value that is $\$ 10$ higher for 
asset 2, which B owns. B is known to have a value of something between 60 and 110 for asset 1 , and a value that is $\$ 10$ lower for asset 2 . If there are separate negotiations over the two assets, economic theory tells us that the marginally efficient deals will not get done. ${ }^{42}$ So it is possible that A will not sell to B even when it is somewhat efficient to do so, and vice versa. But it is easy to see that if the two deals are put together, $A$ and $B$ can agree to swap assets, making each one better off by $\$ 10 .^{43}$

But the real-world transactions with complex side deals appeared to many economists and attorneys at the FTC to be mere fig leafs for cash payments. For example, in the Schering case, (1) the due diligence on the Schering side prior to the purchase of the patents could charitably be described as minimal; (2) there were no significant alternative offers for the patents, let alone alternatives that were comparable to the Schering offer; (3) other rights offered by other firms, which appeared to be more valuable than those offered by Upshur-Smith, were rejected by Schering at much lower prices; and (4) in confirmation, the rights purchased turned out to be worth very, very little. Indeed, some have referred to the licenses that Schering "purchased" as being for "Brooklyn Bridge-izone."

The decision in the FTC case contains the administrative law judge's arguments against all these claims. He also relied on the bargaining argument that sometimes the introduction of additional issues into the mix helps facilitate efficient trade.

There are two problems here. First, I believe that the FTC's skepticism over the value to Schering of the patent rights Schering purchased was well justified. But second, and more important, whether the value to Schering matched its cost was not the right question. To see why, consider the following example. Assume that a bundle of patent rights owned by the generic is worth 10 to the generic, perhaps as the best alternative price it can receive from another buyer, and 90 to the brandname company. Also assume these values are easily observed and verified by everyone. In an arm's length transaction involving the sale of those rights, the price might be 50, or well above the value to the generic. Such a deal would surely happen, regardless of whether there is a separate transaction involving a Paragraph IV filing.

Now imagine that it is bundled in with the Hatch-Waxman case. The incentive of the parties would be to make the price of the right to the patent as high as they could get away with, or to something close to 90 in the example if the Schering judge's arguments are accepted, and at the same time add some delay time to the entry of the generic. The 
bundling of a second, irrelevant deal has become a vehicle for allowing the cash payment of 40 to acquire delayed entry. This problem is exacerbated because the regulatory agencies are at a tremendous informational disadvantage in evaluating not only the probability that a patent litigation would be successful but the value of any side deal, in the absence of clear market alternatives. ${ }^{44}$ In any event, economists (in contrast to the Schering Upshur ALJ) would tend to be skeptical of claims that one firm would have a value for a set of licenses that was a large multiple of the value to the second highest alternative when an industry with as many competitors as pharmaceuticals.

Note that protecting against the abusive potential of a Schering-type deal would not require a prohibition against a brand purchasing additional licenses from a generic as part of a bundled deal that included a Hatch-Waxman settlement. Rather, the necessary requirement to eliminate gaming possibilities would be that the cash paid by a brand in any deal be clearly no higher than what it could have received by selling the extra licenses separately. The parties can then adjust on the margin by shortening the monopoly to achieve the multi-issue bargaining efficiencies that are the efficiency justification for bundling the transactions, rather than increasing it. If the deal falls apart (unless there is a way to buy an extension of the monopoly), then the implication is that the deal did not create substantial efficiencies in the first place. This is especially true given the ambiguous welfare effects of settlements in this area, in light of the 180-day rule.

Again, I emphasize that there is no need to rule out all side deals to eliminate the potential for gaming. For example, generics could include cash or free licenses in a settlement package, and indeed many settlements of patent disputes have involved payments from the generics to the brands. ${ }^{45}$ If a generic had a set of licenses for which it had an alternative offer of 20, then including the licenses for a charge of 15 would be procompetitive. The standard that would ensure that a side deal does not reduce welfare is that the generic would at least weakly prefer to have the total side deal eliminated, were that possible with the Hatch-Waxman deal still getting done on the same terms.

\section{Royalty Payments}

Some deals have involved entrants receiving licenses to enter the market, either immediately or on a delayed basis, with the entrant paying royalties to the brand. Putting aside issues related to the 180 -day rule, 
whether such settlements are procompetitive depends primarily on the shape of the royalty schedule. In the extreme, a fixed one-time payment from the entrant is presumably made to speed entry. A constant marginal royalty rate is presumably also agreed to by the generic as a way of getting into the market sooner. But a royalty rate that increases with quantity sold (for example, 10 cents a pill for the first 100 million pills and 50 cents thereafter) shares important traits with a cash payment to the entrant. In the example, if the entrant sells more than 100 million pills, its situation is the same as if it paid a constant royalty plus received a payment of $\$ 40$ million. Presumably the entrant would have negotiated other terms that would have allowed it to enter sooner or at a lower marginal cost were it not receiving the cash.

\section{Gaming the System with Pseudo-Generics}

One final device that has been used to game the system involves the licensing of pseudo-generics in settlements. A pseudo-generic is the branded drug sold as a generic under license from the brand. One example is the settlement between AstraZeneca and Barr labs over tamoxifen, the most widely prescribed breast cancer drug. Barr, whose CEO is a trial lawyer, was the first filer. It claimed that its license to sell tamoxifen did not trigger its 180-day exclusivity period. Therefore, it claimed that no other generic should be allowed to enter until the expiration of the patent, unless it was first sued by AstraZeneca, then won its case, then waited 180 days. To add to the insult, the deal limited Barr to charging 5 percent less than Zeneca's brand-name Nolvadex. The Barr position was initially upheld but was overturned on appeal. As Federal District Judge Ricardo Urbina perceptively observed, "Hatch-Waxman intended to provide an incentive for drug companies to explore new drugs, not a market 'windfall' for crafty, albeit industrious market players." ${ }^{\prime 4}$

In a 2001 settlement, Pfizer similarly agreed to give Mylan a license to sell a generic version of Procardia XL 30 as settlement of its litigation. In this case, the FDA subsequently required Mylan to change its ANDA application to a Paragraph III filing on the grounds that the settlement implied that the patent was valid and Mylan was not contesting it. In this way the FDA managed to prevent the settlement from blocking other potential generic entrants.

From a game theoretic perspective, it is easy to see how pseudogenerics can be used as an entry deterrent even in the absence of a 
Hatch-Waxman settlement. Some deterrence tactics may be legal, others not. Clearly, though, the introduction of a competing pseudogeneric will reduce the profits of any generic that wins a Paragraph IV case (or plans to enter after patent expiration), especially since the pseudo-generic will be a perfect substitute for the brand and it may be brought to market before the generic. Even in cases where the pseudogeneric's impact on the brand's profits may be ambiguous, it will at least serve to enhance a reputation of the brand-name company that it will make challenging its patents as unprofitable as possible. As an example, in April 2003, GlaxoSmithKline submitted a proposed settlement of a Paxil infringement suit with Pentech, one of the later filers. While the agreement has not been made public, it apparently may license Pentech to sell a pseudo-generic Paxil whenever Apotex, the first filer, finally is approved.

\section{Policy Issues}

In this section, I discuss proposals for changing Hatch-Waxman, largely focusing on the elimination of the current gaming incentives.

\section{Revising or Eliminating the Thirty-Month Rule}

If an entrant loses a patent infringement case, it is liable for damages that it causes the patent holder. The patent holder might legitimately request a preliminary injunction (PI) that would either deny entry or require the entrant to put up a bond against potential damages. If the law did not allow for PIs, a judgment-proof entrant could unfairly damage a patent holder. The entrant might be able to force the patent holder to pay it for not entering or, if the FTC prohibited that option on antitrust grounds, it might be able to force the patent holder to allow it to enter the market some time before the legitimate expiration of the patent.

It seems fair that patent holders be given notice of the intent of a generics manufacturer to infringe on one of their patents, and that they have time to request a preliminary injunction. The current notice provisions and the forty-five-day rule seem adequate, especially because it takes a considerable amount of time for an ANDA to be approved, thus allowing the incumbent time to get a PI. But if the brand can get a stay against entry whenever a judge believes that it is appropriate, one might question the necessity of having the automatic thirty-month stay and all the gaming that it implies. 
One argument of the advocates of the current rules is that the thirtymonth stay was part of a complex bargain that included the introduction of ANDAs and changes to the rules regarding patent life. Maintaining incentives for pharmaceutical R\&D might therefore require accompanying the elimination of the thirty-month stay with a change in patent life. Perhaps so, but it is unclear what the thirty-month stay does, beyond saving the trouble of filing for a PI, if a patent holder does not use it to game the system. Even without a PI, a generics firm would not enter a market before a verdict unless either (1) it really is judgment-proof or (2) it has reason to be extremely confident of winning its case. The thirty-month rule has an effect only when a patent holder is unable to obtain a PI because its case is not strong enough, or when it is gaming the system with sequential filings. It is hard to imagine that the legislative bargain that produced the thirty-month rule was meant to cover those cases. That said, because of the thirtymonth stay, patented new chemical entities are currently effectively guaranteed for up to seven and a half instead of five years of exclusivity. It is possible, if the thirty-month stay rule were eliminated, Congress might reasonably choose to extend the exclusivity period of new chemical entities.

The FTC has proposed limiting brands to one thirty-month stay per new chemical entity. Given that the average length of litigation (when there is only one stay) is over two years and it is unlikely in most cases that a generic would enter the market until it was reasonably confident of a legal victory, such a proposal would cause little delay in entry, assuming that brands would generally be able to obtain a stay. ${ }^{47}$ In June 2003, the Health, Education, Labor, and Pensions Committee of the Senate approved a one thirty-month stay limit in the proposed S.1225 Greater Access to Affordable Pharmaceuticals (GAAP) by a vote of 21-0. In addition, if a generic is not sued within forty-five days of brand notification, it would be beneficial to allow it to sue to obtain affirmation that it is noninfringing. GAAP also includes this provision.

\section{Revising the 180-Day Rule}

Several thoughtful analysts have proposed either elimination or revision of the 180-day rule. ${ }^{48}$ Under the McCain-Schumer Greater Access to Affordable Pharmaceuticals Act, ${ }^{49}$ the exclusivity of the first filer would forfeit and roll to the second filer under certain conditions, such as fail- 
ure to get tentative product approval within thirty months, failure to win the lawsuit, or the settlement of a lawsuit with the brand-name company that acknowledged patent validity. Reform in the rule is clearly essential; the real question may be, Can the rule be justified at all?

The justification for the 180-day rule must be to give entrants a fair share of the value that their entry creates. That is, it must imply some market imperfection that would cause the volume of entry to be too low without the provision. Typically, economists would argue that an entrant to a market should be rewarded on the basis of the value it creates. Value is generally thought of as the sum of the profits of the existing firms and the benefits that consumers reap from the market. Within antitrust law, consumer benefits are given much greater weight than are profits. An entrant who can create a new product that is superior to the old, or who can produce an old product more cheaply than anyone else, will be able to benefit in proportion to the degree to which its products are superior to those already in the market. But with generic drugs, the benefit that the entrant provides is somewhat different: it is competition.

No one thinks of the generic product as superior to the brand-name product. At the very best, it is identical. It is exceedingly unlikely that a generics firm will have lower production costs than the brand-name firm that has been selling a medicine for years. What the generic provides, then, is competition. Consumers will benefit by being able to buy a bioequivalent substitute at a reduced price. The lower price may increase efficiency by bringing in new customers who would otherwise be priced out of the market, and similarly by causing competitors to lower their prices and also bring in new customers. But the reality is that these efficiencies are probably not primary. What the generics really contribute to efficiency is to make the patent system work as Congress intends. Developers of good patents are appropriately rewarded for the appropriate length of time, while those whose claims are invalid are not so rewarded. It is less costly for the government to award long patents as an incentive for legitimate innovation if it is less concerned that doing so will also allow long periods of exclusivity to those who did not develop a valid patent claim. ${ }^{50}$

One problem with the current system is that it rewards entrants based on filing date, not on actual contribution. The entrant who has really contributed something is the one who wins the litigation that makes entry feasible, not the first firm to file. Consistent with the concept that firms should be rewarded for what they contribute, any exclu- 
sivity period would most efficiently be granted to the first firm to make entry feasible. Such a change would go a long way to eliminating the gaming possibilities available under the current law because agreements by one firm could no longer be used to postpone entry by a second.

However, there is still the issue of whether the 180-day exclusivity period is at all justifiable. The argument against it is that it is not available in other industries, so the only reason to make it available in pharmaceuticals is that the industry is somehow different. The response is two-part. First, what is the justification for an exclusivity period? Second, what is it about pharmaceuticals that might be different from other industries in which there are patent contests?

The justifications for the exclusivity period derive from the time and costs of the legal system. If the legal system could provide an instantaneous and cost-free resolution of all patent disputes, then any generic entrant could enter the market as soon as it had a product that did not use any valid patents. It would be the exclusive generic until a second generic firm came along with a similar product. Assuming that the entrance of the first firm neither speeds nor slows the entrance of the second firm, then the first firm would have exclusivity for exactly the period by which it speeded generic entry to the market. Its entry would provide benefits for both the firm and consumers.

But if the legal system is costly and time consuming, then problems arise. Assume that it takes eighteen months and several million dollars to litigate a patent case. Generic A develops its product twelve months before generic $B$. At the end of eighteen months, A wins its litigation and the patent is declared invalid. If $A$ and $B$ were able to enter the market on the same day, A would make very little money, and get little compensation, for its contribution in speeding generic entry by a year and saving B a year's worth of litigation expense.

Were the verdict for $A$ noninfringement, then the argument is more complex. If A's victory did not speed B's entry or save B litigation expense, then there would be no justification for guaranteeing a minimum of 180 days of exclusivity. But if, for example, A's victory enabled $B$ to predict victory confidently and overturn a preliminary injunction against its entry, then A's victory would speed B's entry into the market, perhaps leaving A with little to show for its efforts. Similarly, if A were well ahead of B in development but a judge consolidated A's and B's litigation, then the resolution of B's case might be speeded by A's actions, depriving $A$ from benefiting from its contribution of speeding generic entry. 
One caveat noted by Engelberg (1999) is that the generics business has evolved greatly since the Hatch-Waxman Act. Now, generics are likely to have patent lawyers routinely screening Orange Book listings. When a questionable patent is filed, several generics often will invest in the six to twelve months of data needed to file an ANDA, almost simultaneously. In such cases, the 180-day rule gives the first filer more exclusivity than its marginal social contribution to early entry. ${ }^{51}$

Beyond this, there remains the question of whether this problem, namely, that the litigation process may deprive a successful generic of some of the benefits of its contribution, is sufficient to merit special rules. Couldn't the same argument be made in other types of patent litigation? No one is proposing a 180-day rule in those markets.

Pharmaceuticals may well be different. The difference has to do with the sort of products that generic manufacturers sell. The goal of a generic is to produce as perfect a substitute for a brand-name drug as possible, and any other users of the patent would attempt the same. ${ }^{52}$ In other sectors, potential users of the patent may be nonrivalrous, or at least may produce highly differentiated goods. In other patent cases, the dispute is very likely to be quite different. For example, high-tech companies that engage in patent cross-licensing are likely to be producing products that do not directly compete with each other. While AMD and Intel compete directly, their products still differ, and most of the firms that license Intel's patents, or whose patents Intel licenses, produce products that are quite different from Intel's. Pharmaceuticals are unusual because the entrant proposes to clone as closely as possible a final product sold directly by the patent holder. In other markets, disputes may be about patents that represent a relatively small fraction of the value of the user's product, for example, a patent on windshield wiper technology that a car manufacturer might wish to use, or a technology for producing clean gasoline. In generic drugs, however, the patent represents almost the entire value of the product.

Of course, this analysis is highly speculative. It merely means to suggest that there may be a reason why the incentives for potential entrants in pharmaceutical cases would be less under the conventional patent litigation system than they are in other industries. A guaranteed exclusivity period for the first firm to win its litigation might thus be appropriate, if its litigation is likely to speed entry by competitors. Whether 180 days is the right number is an empirical matter. Roughly, the questions are: How much of a lead would the first victorious litigant have if its litigation had no effect on the entry date of other firms? 
How much of a lead is it likely to have in the real world where its litigation does affect competitors' entry? And how much of an exclusivity period would be needed to restore the appropriate entry lead?

With an average of approximately four filers per patent, the 180-day exclusivity has certainly helped to attract many generic firms, but the alternative inference is that exclusivity is no longer warranted. Welfare would be increased by requiring the forfeiture of any right to 180-day exclusivity by any firm that agrees to a delayed entry settlement. The justification given above for retaining the exclusivity is that a litigation victory by A might speed B's entry into the market, and so A would not be adequately compensated for its work as the first filer. If A settles its litigation with no acknowledgment of patent noninfringement or invalidity, then it has arguably not speeded B's entry into the market. In this case, B might still be eligible for some exclusivity, up to 180 days, if it won its case prior to the date at which $A$ was scheduled to enter the market, subject to its exclusivity not deferring A's date of entry.

As to when the 180 days would begin, the FTC study argues that it should start after the first legal decision, even if the case is appealed and the firm does not enter. This is the current interpretation of the law. There are legitimate reasons for not entering until an unappealable verdict is reached, so a rule of starting the clock on entry or on winning a final verdict, which was the FDA's original interpretation of the law, might make more sense, at least when combined with vigorous enforcement of anticompetitive settlements.

The GAAP bill also addresses 180-day exclusivity by requiring its forfeiture if the applicant either fails to receive approval within thirty months, fails to enter within sixty days of a favorable appellate verdict, or is found by the FTC to have engaged in an unlawful settlement.

In summary, while there are arguments both for and against the 180day rule, its current implementation creates gaming problems. Proposals that require the forfeiture of the exclusivity period on the signing of any delayed entry agreement are designed to prevent firms from taking actions that defer the entry of third parties.

\section{Pseudo-Generics}

The difficulty in dealing with pseudo-generics is that it is hard to argue against a company's licensing another firm to manufacture and sell its product under another name, even if there is a deep suspicion that the motive was anticompetitive. To some extent, the companies are limited by the most-favored-customer rules imposed by the Medicaid Best Price 
Statute. If the brand-name company itself sells a pseudo-generic at a lower price and then charges Medicaid the higher price for the brand, then it is breaking the law. Bayer was fined $\$ 250$ million for alleged overcharges on high-blood-pressure drug Adalat and antibiotic Cipro. It also paid a $\$ 5$ million criminal penalty. GlaxoSmithKline licensed health maintenance organization (HMO) to become a generic manufacturer of Paxil, which the HMO then sold only to itself. It agreed to an $\$ 87.6$ million fine but was not criminally charged. ${ }^{53}$ These cases are an indication that future pseudo-generic production is unlikely to come from generic subsidiaries of the brand-name manufacturers.

We have also the broader issue of whether pseudo-generics constitute a form of predation even when they are sold at prices above marginal cost. ${ }^{54}$ There are at least four clear theories of how pseudogenerics deter entry. The first, already discussed, is reputational. The second is that, in some cases, a pseudo-generic introduced shortly before patent expiration could deter other generic entry because surely there are advantages (versus other generics) to being a perfect substitute for the brand and to being the first generic available to customers. The third, of course, is that even without early entry, the pseudogeneric allows the brand to compete for price-sensitive customers with selective discounting rather than through a general price reductiona typical price-discrimination story. Fourth, the threat of the brand being able to introduce a pseudo-generic whenever a true generic is ready to come to market will reduce entry.

To elaborate on the fourth point, consider the early days of competition in long-distance telephony. AT\&T, the dominant player, was required to post price changes 120 days in advance, while entrants $\mathrm{MCI}$ and Sprint could cut prices in a day. Consumers could alternately benefit from a substantial incentive to enter or from AT\&T pre-empting entry through low prices. The analogy here would be a rule that, say, required brands to announce the introduction of a pseudo-generic two years ahead (easy to do because there are no regulatory hurdles), presumably with a price attached. ${ }^{55}$ Of course, this issue is not unique to pharmaceuticals - it applies to entry against many other dominant firms. While one may be sympathetic to this argument, it goes beyond pharmaceuticals and beyond the scope of this paper.

One response by governments that were concerned with the use of pseudo-generics as a price-discrimination and entry-deterrence device would be to build on the Medicaid statute by requiring the substitution of a cheaper pseudo-generic whenever available for any prescription that specifies the brand. 


\section{Banning Cash Settlements and Related Mischief}

There is reason to be deeply skeptical of the efficiency justifications for reverse payments from the licensor to the licensee. Also, because the value to the brand-name company of keeping the generic out is vastly greater than the value to the generic of getting in, it is clear that if we allow complex settlements, the overwhelming incentive of the parties will be to game the system by transferring resources to the entrant in return for a postponed entry date.

This does not mean that all settlements, or even that all settlements in which other resources are part of the settlement, are anticompetitive. Many of the settlements without reverse payments that were listed in the FTC report may have been legitimate, with a reservation only about their interaction with the 180-day rule as currently applied. Settlements in which entrants clearly make a financial sacrifice to finish the deal, for example, by selling patent rights to the brand at a price below what others have offered for the same rights, would be acceptable. An alternative rule that allowed settlements whenever the brand could argue that it did not lose on the side deal, even as the entrant gained substantially, would create an incentive to transfer most of those gains to the entrant in return for a delayed entry date.

The bottom line is, paying competitors to stay out of the market may be profitable, but doing so reduces competition and is likely to attract very close antitrust scrutiny.

\section{Notes}

I wish to thank Richard Feinstein and Dan Kotchen of Boies Schiller and Flexner LLP for their enormous contributions to the first four sections of this paper. Audiences at the NBER Conference on Innovation Policy and the Economy, Stanford Law School, and Stanford Business School also made several valuable suggestions. Paul Klemperer and John Morgan made numerous contributions to the economic analysis, and Tim Gilbert made several useful comments on the legal issues. I was director of the Bureau of Economics of the Federal Trade Commission from late 1998 until 2001, and I acknowledge a great debt to my colleagues there who worked on these cases. In the past, I consulted for a generic drug company but not as a member of any litigation team. I am solely responsible for all errors and for the conclusions expressed herein.

1. Drug Price Competition and Patent Term Restoration Act of 1984, Pub. L. No. 98-417, 98 Stat. 1585 (codified at 21 U.S.C. $\S \S 301-397$ [2001]). A summary of relevant portions of the Hatch-Waxman Act is set forth in Section 2.

2. FTC v. Hoechst Marion Roussel, Inc., Carderm Capital L.P. and Andrx Corp., Docket No. 9293 (consent order issued May 8, 2001) (FTC Commission Actions: May 11, 2001 [referred to as "Hoechst-Andrx"]); Abbott Laboratories and Geneva Pharmaceuticals, Inc., C-3945, 
C-3946 (consent orders issued May 22, 2000) (FTC Commission Actions: May, 26, 2000 [referred to as "Abbott-Geneva"]); and In the Matter of Bristol-Myers Squibb Company FTC files 001 0221, 011 0046, and 0210181 (referred to as "Bristol-Schein"). The Bristol Myers consent covered not only an agreement between Bristol and Schein involving BuSpar, but also alleged Hatch-Waxman abuses by Bristol involving BuSpar, Taxol, and Platinol.

3. Schering-Plough Corp. Upsher-Smith Laboratories, and American Home Products Corp., Docket No. 9297 (complaint issued April 2, 2001) (FTC Commission Actions: April 2, 2001 [referred to as "Schering"]). Note that, as part of this matter, American Home Products and its subsidiary ESI Lederle signed a consent agreement with the FTC.

4. In re Cardizem CD Antitrust Litigation, 105 F. Supp. 2d 682 (E.D. Mich. 2000) (on appeal to the Sixth Circuit); In re Terazosin Hydrochloride Antitrust Litigation, 164 F. Supp. 2d 1340 (S.D. Fla. 2000) (on appeal to the Eleventh Circuit).

5. Private plaintiffs have challenged the same agreements involving Schering, UpsherSmith, and ESI Lederle that are at issue in the FTC case. Suits have also been filed challenging an agreement between Bayer A.G. and Barr Laboratories, Inc. A federal district court has issued a decision in this case, which provides a factual background of the Hatch-Waxman Agreement at issue. See In re Ciprofloxacin Hydrochloride Antitrust Litigation, 166 F. Supp. 2d. 740 (E.D.N.Y. 2001).

6. In a paper written contemporaneously with this one, Hovenkamp et. al. (2003) look at anticompetitive patent settlements more broadly, with special focus on the HatchWaxman cases. They propose a three-part test to determine whether a settlement is problematic: (1) Would the settlement be problematic if it were not an intellectual property settlement? (2) Is the settlement more anticompetitive than litigation? (3) Are there alternatives to the settlement that would be less restrictive? Their substantive conclusions are broadly consistent with the conclusions of this paper.

7. Much of this overview is taken from Chapter 1 of a July 2002 Federal Trade Commission study entitled "Generic Drug Entry Prior to Patent Expiration" (available at www.ftc.gov) ("FTC Generic Drug Study"), and Congressional Budget Office (1998).

8. After the Uruguay Round Agreements Act of 1994, the patent term was changed from seventeen years from patent grant to twenty years from application filing.

9. An extension may also be granted for a process patent, which can often be invented around by a generic.

10. See Congressional Budget Office (1998) and Grabowski and Vernon (1986).

11. This includes patents covering the active ingredient, specific formulations, and methods of use.

12. The publication is entitled "Approved Drug Products with Therapeutic Equivalence."

13. In this article, I refer to ANDAs with Paragraph IV certifications as "Paragraph IV ANDAs."

14. On average, when there is no lawsuit, it will take a successful ANDA filer 24.5 months to gain approval.

15. Pharmaceutical patent cases begin in District Court and then go to the Court of Appeals. The FDA originally interpreted this provision as applying to a final, unappealable 
verdict, but for ANDAs filed after March 2000, the thirty-month stay ends with a District Court verdict in favor of the generic. The FTC estimates that the average time from filing to a district court verdict in Paragraph IV cases has been 25.5 months, but the time can be extended by an appeal. In recent years, as Orange Book filings have listed more patents, the length of litigation has increased.

16. On various occasions, the FDA has used either a District Court or an Appeals Court decision to motivate the start of the 180-day clock.

17. I refer to the restraint within this provision of the agreement as a relinquishing restraint. A similar provision was also included in the Abbott-Geneva agreement.

18. I refer to the restraint within this provision of the agreement as a noninfringing restraint. A similar provision was also included in the Abbott-Geneva and Schering and Upsher-Smith agreements.

19. Presumably this was usually because it was clear that the generic's product did not infringe, though it is possible in some cases that the brand simply did not feel a lawsuit was worth the cost. The majority of products that did not provoke suits had sales of under $\$ 100$ million per year, while the median volume for those that did lead to litigation was $\$ 190$ million (Federal Trade Commission 2002, p. 14). Also, in some cases, the brand may have simply felt that the generic would be unable to come to market before the expiration of the patent anyway; in two cases, the patents did expire before the FDA approved the ANDA.

20. See FTC, In the Matter of Biovail Corp. and Elan Corp., File No. 011 0132, Agreement Containing Consent Order, available at http://www.ftc.gov/os/2002/06/ biovailelanagreement.pdf.

21. Cotter (2003) argues persuasively that litigation costs are often significant. However, significant litigation costs will generally improve the bargaining position of the brand because such costs will be a smaller fraction of the amount it has at risk. Therefore, high litigation costs would imply that settlements without monetary transfers would already postpone entry beyond the actuarially fair date.

22. The reason is that, while generic entry does not appear to lead to lower brand prices (Frank and Salkever [1997] actually find an increase), it does lead to lower generic prices. So the implication is that the brand loss from one versus two entrants is proportional to lost sales, while the consumer benefit is greater than that because of the price reduction caused by the second generic. The assumption would not hold if the elasticity of overall demand with respect to the generic's price was much greater for entry of the first firm.

23. Note that while the settlement is actuarially better than fair, the number of expected monopoly days increases because the exclusion period is all days that would have been monopoly days, while the entry period includes days in which the second filer may have entered.

24. If the settlement were contingent on the outcome of the second filer's litigation, including immediate entry if the second filer won, then an actuarially fair settlement would make everyone no better or worse off.

25. Or even more profitably, the firms could theoretically agree to contingent entry, with the entry date negatively correlated with the second firm's litigation success.

26. See, for example, Reiffen and Ward (2002), who estimate the impact of multiple entrants on prices. 
27. In the Nash bargaining solution, the settlement will be such that the ratio of the marginal value of an extra piece of the pie to the average value (above their threat point) must be the same for all bargainers. At the level of the risk-neutral settlement, the entrant, who has much less at stake, will have a higher ratio of marginal value to average value than will the brand and therefore will be able to credibly insist on a better deal.

28. This is precise with Cournot oligopoly and linear demand. Assume a market demand curve of $p=a-b Q$, where $Q$ is the sum of the brand's and the generic's output. Marginal costs are normalized to zero for the brand; for the entrant, they are equal to a royalty rate $\mathrm{z}$. The royalty rate determines the quantities and profits of the two firms. The quantity-setting equilibrium is that the market quantity is $(2 a-z) / 3 b$; market price is $(a+$ $R) / 3$; the entrant earns $(a-2 z)^{2} / 9 b$; and the brand earns $(a+z)^{2} / 9 b+z(a-2 z) / 3 b$, the latter expression being its royalties. The derivative of entrant profits with respect to $R$ is $-4(a-2 R) / 9 b$, while the derivative of brand profits is $5(a-2 z) / 9 b$. Thus, for any royalty rate below $a / 2$ (at which no entry occurs), the monopolist loses $\$ 5$ in profits for every $\$ 4$ gained by the entrant. For the case of generics, assume that the brand's price does not change in the face of generic competition, as appears to be roughly true. Thus, a cut in the royalty rate provides a first-order increase in profits to the generic, which can maintain its old price. The generic can also choose to cut price a bit further, which it would likely do, having a second-order impact on its own profits but a first-order impact on the brand's, which would make the brand's profits fall by more than the gain to the generic.

29. Because the generic and the brand are not, in fact, completely identical products, the comparison becomes more difficult. For example, assume that production costs are identical but consumers would pay a bit more for the brand, perhaps because they prefer the brand's "fills" or think that it is less risky. Also assume that the entry of a brand leads to an overall increase in sales but a decrease in the sales of the incumbent. Then generic entry, while it will always necessarily increase consumer surplus, might be inefficient. The issue for efficiency is whether the margins on the new customers brought into the market by the presence of the generics are greater or smaller than the lost efficiency from consumers who would have bought the brand but now switch to a generic that they value less, while the two producers have the same marginal costs of production. See Bulow, Geanakoplos, and Klemperer (1985), pp. 504-505. As I argue later, the real value that the generics provide may be through appropriate enforcement of the patent laws.

\section{See Engelberg (1999), p. 415.}

31. A metabolite is the chemical compound in which a patient's body metabolizes the drug. Sometimes it is the metabolite that causes the therapeutic effect. Of course, only the patient can directly infringe such a patent, but patentees will claim that the generic helps create the infringement. One district court has ruled that a metabolite patent does not "claim the drug," as required in Hatch-Waxman, and such patents should not be listed.

32. More than one chemical structure may create the same active ingredient. If polymorphs are substantially identical, then the various polymorphs that create the same active ingredient as the one for which the brand obtains its NDA would appear to be eligible for inclusion under the brand's original patent. However, if the polymorph is substantially identical it would appear to be precluded from patenting several years after the initial filing, based on the prior art of the original. On the other hand, if the polymorph is not substantially identical, then the production of the polymorph would not seem to infringe on the NDA and the polymorph would not appear to qualify for Orange Book listing. Further, even if late patenting of the polymorph were permissible under a theory of "double patenting" (see footnote 34), we have the separate issue 
of whether firms should be allowed to use this technique to restart the thirty-month clock.

33. Patents about the way the drug is made.

34. To this end, some have argued that an expedited administrative system of determining patent legitimacy (or, in this case also, relevancy to the production of the chemical entity) would be extremely helpful. See, for example, Merges (1999) and Levin and Levin (2002).

35. When a new patent would be invalidated by the applicant's own prior art, the patent office will sometimes agree to the new patent conditional on the termination date being set equal to the termination date of the original patent. The FTC study discusses Bristol Myers's double patenting of Platinol (cisplatin) (Federal Trade Commission 2002, pp. A34-A35).

36. The material in this section is based on Buehler (2001).

37. Of course, financial market theory says that if the management were operating in the best interests of its shareholders, it would have been risk-neutral relative to this risk if the risk were not correlated with the stock market as a whole.

38. Schering had approximately $\$ 500$ million in unrealized pension losses at the end of 2002. While hardly alone, the decision of the company to gamble with its pension assets rather than hedge its benefit liabilities is relevant to any discussion of its risk tolerance.

39. Okay, they don't quite say it this way, but it is what they say.

40. While these payments were referred to as loans in the deal documents, lawyers were evasive when asked whether, for tax and accounting purposes, the companies treated the payments as income and expense or as loans.

41. That said, the FTC study reports that out of fourteen cases where the brand appealed a district court verdict, the generic won thirteen times. The last case was a split decision in which one of two patents were upheld.

42. The classic reference is Myerson and Satterthwaite (1983).

43. Actually, mechanism design theory suggests that the parties in this example might do even better by initially agreeing to swap about half of the two assets rather than 100 percent, and then using a bargaining mechanism as proposed by Cramton, Gibbons, and Klemperer (1987), which could likely achieve full efficiency.

44. Leary (2001) rightly points to this as an additional reason to be skeptical of any reverse payment settlements. This viewpoint is in contrast to the analysis of Blair, in Blair and Cotter (2002), who argued that, because the FTC could not estimate the outcome of litigation, any reverse payment that was less than 100 percent of what the entrant would have earned from marketing a noninfringing product should be lawful. Cotter (2003) argued that Blair's approach was too extreme; his preferred methodology (Blair and Cotter 2002) would be a "quick look" approach, in which the burden of the plaintiff would be to show that reverse payments had been made, with the burden then shifting to the defendant to show that the settlement was nevertheless not anticompetitive.

45. Licenses with royalty fees, where the marginal royalty rate did not fall with quantity sold and where the brand was not obligated to produce the licensed product, also do not appear to create any gaming incentives. 
46. Quoted in "How Companies Stall Generics and Keep Themselves Healthy," by Sheryl Gay Stolberg and Jeff Gerth, The New York Times, Section 1, page 1. July 23, 2000.

47. One argument of the brands has been that, as a practical matter, they might have trouble obtaining a stay even when the merits of the case point toward their receiving one. Without commenting on the merits of this argument, the one automatic-stay provision would address this concern.

48. Rosenthal (2001) wrote a very good paper advocating the McCain-Schumer bill discussed below; Engelberg (1999) preceded the bill and presents the case for eliminating both the thirty-month and 180-day rules.

49. S. 812,107 th Cong. (2001).

50. Note, however, that the benefits created by the generic may exceed those suggested by looking at the generic demand curve. That is because of the moral hazard problem caused by third-party payment for medicines. Therefore, looking at the price differential that is required to have a consumer switch to a generic will overstate, perhaps substantially, the consumer's preference for the brand and equally any social costs of a switch.

51. If we think of generic entry decisions being made stochastically, a firm would still profit, even without the 180 days in the one case where it added value-namely, when there were no other entrants. Of course, one could always argue that generics provide a particularly high (or low) amount of social benefit per dollar of profit they earn, and so it would be efficient to subsidize (tax) them. I also note that there are cases when the 180-day rule is of no practical value because, for example, the brand may have won an additional three years of "pediatric exclusivity." In this case, even if the generic wins its case, it cannot enter until the end of the exclusivity period, but the 180-day clock starts immediately on a verdict.

52. One of the reasons that pseudo-generics, or branded drugs sold separately as generics, are such tough competition is that they are, in fact, identical to branded drugs, down to the last filler ingredient. That makes them a more perfect substitute than any other possible product.

53. See "Drug Co.'s Settle Medicaid Fraud Suits," April 16, 2003, at CBSNEWS.com. See also the press release "GlaxoSmithKline, Government Reach Civil Settlement," April 16, 2003, on the Glaxo web site. <www.gsk.com/media/archive.htm> accessed June 2, 2003.

54. See, for example, Liang (1996) and Hollis (2003).

55. Edlin (2002) alternatively suggests that if an entrant undercuts an incumbent by 20 percent or more, the incumbent should be prohibited from responding for twelve to eighteen months.

\section{References}

Blair, Roger D., and Thomas Cotter. 2002. "Are Settlements of Patent Disputes Illegal Per Se?" Antitrust Bulletin 47: 491-539.

Buehler, Gary. 2001. "Shared Exclusivity for Omeprazole," Letter to Andrx Pharmaceuticals. Food and Drug Administration Office of Generic Drugs Center for Drug Evaluation and Research. 
Bulow, Jeremy I., John D. Geanakoplos, and Paul D. Klemperer. 1985. "Multimarket Oligopoly: Strategic Substitutes and Complements." Journal of Political Economy 93(3): 488-511.

Congressional Budget Office. 1998. "How Increased Competition from Generic Drugs Has Affected Prices and Returns in the Pharmaceutical Industry." Washington, DC: Congressional Budget Office.

Cotter, Thomas. 2003, May. "Refining the 'Presumptive Illegality' Approach to Patent Settlements with Reverse Payments: A Comment on Hovenkamp, Janis, and Lemley." 87 Minnesota Law Review 6, June, 1789-1816.

Cramton, Peter, Robert Gibbons, and Paul Klemperer. 1987. "Dissolving a Partnership Efficiently." Econometrica, 55(3): 615-32.

Edlin, Aaron. 2002. "Stopping Above-Cost Predatory Pricing." The Yale Law Journal 111(4): 941-91.

Engelberg, Alfred B. 1999. "Special Patent Provisions for Pharmaceuticals: Have They Outlived Their Usefulness?" IDEA The Journal of Law and Technology 39(3): 389428.

Federal Trade Commission. 2002. "Generic Entry Prior to Patent Expiration: An FTC Study." Washington, DC: Federal Trade Commission. July 2002. Available at <www.ftc.gov/opa/2002/07/genericdrugstudy.htm>. Accessed on August 4, 2003.

Frank, Richard, and David Salkever. 1997. "Generic Entry and the Pricing of Pharmaceuticals." Journal of Economics and Management Strategy 6: 75-90.

Grabowski, Henry, and John Vernon. 1986. "Longer Patents for Lower Imitation Barriers: The 1984 Drug Act." American Economic Review 76(2): 195-98.

Hollis, Aidan. 2003. "The Anti-Competitive Effects of Brand-Controlled 'PseudoGenerics' in the Canadian Pharmaceutical Market." Canadian Public Policy (Analyse de Politiques) XXIX(1): 21-32.

Hovenkamp, Harold, Mark Janis, and Mark A. Lemley. 2003. "Anticompetitive Settlement of Intellectual Property Disputes." 87 Minnesota Law Review 6, June: 1719-66.

Leary, Thomas B. 2001. "Antitrust Issues in the Settlement of Pharmaceutical Patent Disputes, Part II." Journal of Health Law 34(657): 661-62.

Levin, Jonathan, and Richard Levin. 2002. "Patent Oppositions." Stanford University. August. SIEPR Policy Paper No. 01-029.

Liang, Bryan A. 1996. "The Anticompetitive Nature of Brand-Name Firm Introduction of Generics Before Patent Expiration." The Antitrust Bulletin 41: 599-635.

Lourie, Alan D. 1989. "A Review of Recent Patent Term Data." Journal of the Patent and Trademark Office Society 41: 171-76.

Merges, Richard. 1999. "As Many As Six Impossible Patents Before Breakfast: Property Rights for Business Methods and Patent System Reform." Berkeley Technology Law Journal 20: 77-91.

Myerson, Roger B., and Mark Satterthwaite. 1983. "Efficient Mechanisms for Bilateral Trading." Journal of Economic Theory 29(2): 265-81. 
Reiffen, David, and Michael Ward. 2002. "Generic Drug Industry Dynamics." Working Paper. Washington, DC: FTC Bureau of Economics.

Rosenthal, Julia. 2002. "Hatch Waxman Use or Abuse? Collusive Settlements Between Brand-Name and Generic Drug Manufacturers." Berkeley Technology Law Journal 17: 317-35. 